\title{
Maitorotuisten sonnien energia- ja valkuaisruokinnan tarkentaminen
}

\author{
Arto Huuskonen \\ Maa- ja elintarviketalouden tutkimuskeskus, Kotieläintuotannon tutkimus, Halolantie 31A, 71750 \\ Maaninka,arto.huuskonen@mtt.fi
}

\section{Tiivistelmä}

Tutkimusaineisto perustuu MTT:1lä 2000-luvulla toteutettuihin maitorotuisten sonnien ruokintakokeisiin. Tutkimuksen tavoitteena oli tuottaa tietoa, jonka perusteella voidaan arvioida ja kehittää biologisesti ja taloudellisesti tehokkaita energia- ja valkuaisruokintastrategioita maitorotuisille sonneille, jotka kasvatetaan yli $300 \mathrm{~kg}: n$ teuraspainoihin nurmisäilörehuun perustuvalla ruokinnalla. Koeruokinnat toteutettiin joko perinteisesti käytetyillä (rehuvilja) tai vaihtoehtoisilla (elintarviketeollisuuden sivutuotteet) väkirehuilla. Tämän artikkelin tavoitteena on edellä mainitun aineiston perusteella tarkastella Suomessa tällä hetkellä käytössä olevien energia- ja valkuaisruokintasuositusten soveltuvuutta maitorotuisten sonnien ruokintaan. Toisena tavoitteena on selvittää nurmisäilörehu-vilja-pohjaisilla ruokinnoilla ruokittujen sonnien fosforin saantia suhteessa nykyisiin fosforiruokintasuosituksiin.

Ruokintakokeiden aikana sonnien laskennallinen energian saanti oli keskimäärin $10 \%$ suurempi kuin mitä nykyiset ruokintasuositukset edellyttävät kokeissa toteutuneilla kasvutasoilla. Tämän tuloksen perusteella on olemassa tarve päivittää meillä nykyisin käytössä olevat kasvavien sonnien energiaruokintasuositukset. Sonnien laskennallinen ohutsuolesta imeytyvän valkuaisen (OIV) saanti oli kokeiden aikana keskimäärin 38 \% korkeampi nykyisiin ruokintasuosituksiin verrattuna. Todennäköisesti nykyisin Suomessa käytössä oleva OIV-PVT -järjestelmä ei ole optimaalinen valkuaisarvojärjestelmä yli puolen vuoden ikäisille kasvaville naudoille. Parempien valkuaisruokintasuositusten luomiseksi tarvitaan lisää laskelmia ja erilasten valkuaisjärjestelmien vertailua. Valkuaislisällä ei ole saavutettu merkittävää tuotosvastetta viimeaikaisissa maitorotuisten sonnien ruokintakokeissa. Näin ollen valkuaislisän antaminen yli puolen vuoden ikäiselle maitorotuiselle sonnille on tarpeetonta, kun eläimet ruokitaan hyvälaatuisella säilörehulla (D-arvo yli $65 \%$, rehun säilönnällinen laatu hyvä) ja viljapohjaisella väkirehulla kohtuullisin väkirehutasoin (väkirehuprosentti 25-70 \%).

Ruokintakokeiden perusteella tehdyt laskelmat osoittavat, että useimmissa tapauksissa yli puolen vuoden ikäiset sonnit saavat perusrehuista (nurmisäilörehu, vilja) tarpeisiinsa nähden riittävästi fosforia. Näin ollen lisäfosforin tarjoaminen kivennäisrehujen kautta ei ole tarpeen. Myös lisävalkuaisen antaminen lisää fosforin ylijäämää ruokinnassa, koska valkuaisrehujen fosforisisältö on yleensä säilörehua ja viljaa selvästi korkeampi. Vaikka fosforia yleensä tulee likaa, lihanaudan fosforin saanti kannattaa kuitenkin varmistaa laskemalla. Tätä varten osasta säilörehu- ja viljanäytteistä on hyvä analysoida myös kivennäispitoisuudet rehuanalyysin yhteydessä. Nurmien fosforipitoisuus vaihtelee jonkin verran muun muassa lannoituksen mukaan. Mitä enemmän fosforia on käytettävissä, sitä enemmän sitä päätyy kasviin. Säilörehun fosforipitoisuus vähenee kasvukauden edetessä. Lisäksi kasvilajien välillä on eroja fosforipitoisuudessa. Esimerkiksi timoteissa on muita nurmikasveja vähemmän fosforia. Myös maalaji vaikuttaa kasvien fosforipitoisuuteen. Eloperäisillä mailla kasvaneessa säilörehussa on enemmän fosforia kuin karkeilla kivennäismailla tai savi- ja hiesumailla kasvaneessa säilörehussa. Säilörehun kivennäisanalyysillä onkin tärkeä merkitys ruokinnan suunnittelussa.

Asiasanat: naudanlihantuotanto, sonnit, energia, valkuainen, fosfori, ruokintasuositukset 


\section{Johdanto}

Tutkimusaineisto perustuu MTT:1lä 2000-luvulla toteutettuihin maitorotuisten sonnien ruokintakokeisiin. Tutkimuksen tavoitteena oli tuottaa tietoa, jonka perusteella voidaan arvioida ja kehittää biologisesti ja taloudellisesti tehokkaita energia- ja valkuaisruokintastrategioita maitorotuisille sonneille, jotka kasvatetaan yli $300 \mathrm{~kg}: n$ teuraspainoihin nurmisäilörehuun perustuvalla ruokinnalla. Koeruokinnat toteutettiin joko perinteisesti käytetyillä (rehuvilja) tai vaihtoehtoisilla (elintarviketeollisuuden sivutuotteet) väkirehuilla. Tämän artikkelin tavoitteena on edellä mainitun aineiston perusteella tarkastella Suomessa tällä hetkellä käytössä olevien energia- ja valkuaisruokintasuositusten soveltuvuutta maitorotuisten sonnien ruokintaan. Toisena tavoitteena on selvittää nurmisäilörehu-vilja-pohjaisilla ruokinnoilla ruokittujen sonnien fosforin saantia suhteessa nykyisiin fosforiruokintasuosituksiin.

\section{Tutkimusaineisto}

Tutkimusaineisto koostuu 208 maitorotuisen sonnin tuotantotuloksista ja sisältää neljä erillistä ruokintakoetta, joissa on ollut mukana yhteensä 20 erilaista koeruokintaa. Taulukossa 1 on esitetty lyhyt yhteenveto aineistoon sisältyvistä ruokintakokeista. Yksityiskohtaiset koeasetelmat sekä syönti-, kasvu- ja teurastulokset eri koeruokinnoilla on raportoitu aikaisemmissa tutkimusjulkaisuissa (Huuskonen ym. 2007a,b, Huuskonen ym. 2008, Huuskonen 2009a). Sonnien keskimääräistä energian, valkuaisen (OIV) ja fosforin saantia ruokintakokeiden aikana vertailtiin Suomessa tällä hetkellä käytössä oleviin maitorotuisten sonnien ruokintasuosituksiin (MTT 2006).

\section{Tulokset ja tulosten tarkastelu Energiaruokinta}

Nykyinen Suomessa käytössä oleva energian saantisuositus kasvaville maitorotuisille sonneille (MTT 2006) sekä koeaineistossa toteutunut keskimääräinen energiansaanti on esitetty kuvassa 1 ja taulukossa 2. Kun nykyisiä rehutaulukoiden suosituksia verrataan koeaineiston tuloksiin, vajausta on keskimäärin noin $10 \%$. Toisin sanoen maitorotuinen sonni tarvitsi koeaineistossa noin $10 \%$ taulukkoarvoa enemmän energiaa saavuttaakseen taulukoissa luvatun kasvutason. Tämän tuloksen perusteella on olemassa selkeä tarve päivittää nykyiset maitorotuisten sonnien energiaruokintasuositukset. Lisäksi on huomattava, että koeaineiston eläimet on kasvatettu parsikasvattamossa, jotta eläinkohtainen rehun syönti on voitu mitata luotettavasti. Naudanlihantuotantotiloilla on sen sijaan yleisesti käytössä erityyppisiä karsinakasvattamoja, joissa eläimet voivat vapaasti liikkua. Lisääntynyt liikunta lisää myös jonkin verran eläimen energian tarvetta. Esimerkiksi Tuomiston ym. (2009) tutkimuksessa pihattokasvatus lisäsi maitorotuisten sonnien rehun syöntiä ja energian saantia noin $10 \%$ parsikasvatukseen verrattuna, vaikka eläinten kasvussa ei ollut merkitsevää eroa kasvatusympäristöjen välillä.

Ero suosituksen mukaisen ja kokeessa toteutuneen energiansaannin välillä näytti olevan hieman pienempi erillisruokinnalla (keskimäärin 7,5 \% kokeessa IV) kuin seosrehuruokinnalla (8,5 \% kokeessa I, $12 \%$ kokeissa II ja III) (Taulukko 2). Myös joissakin aikaisemmissa tutkimuksissa on havaittu seosrehuruokinnan lisäävän hieman kasvavien nautojen rehun syöntiä. Esimerkiksi Caplis ym. (2005) ja Keane ym. (2006) ovat raportoineet seosrehuruokinnan lisänneen rehun syöntiä 4-5 \% erillisruokintaan verrattuna. Lisääntynyt rehun syönti ei ole yleensä johtanut merkitseviin eroihin eläinten kasvutuloksissa (Caplis ym. 2005, Keane ym. 2006).

\section{Valkuaisruokinta}

Tämän tutkimuksen aineistossa valkuaislisä ei lisännyt sonnien kasvua yhdessäkään osakokeessa (Huuskonen ym. 2007, 2008, Huuskonen 2009a). Rehuannoksen valkuaispitoisuuden vaikutuksia nautojen kasvuun eri ikävaiheissa on tutkittu runsaasti. Mitä paremmin perusruokinnasta saatava energia ja ravintoaineet riittävät tyydyttämään nautojen geneettisesti määräytyvästä kasvutaipumuksesta johtuvan valkuaisen tarpeen, sitä pienempi on lisävalkuaisella saatu kasvun lisä (Huuskonen 2009b). Valkuaisen syötöstä on siis oletettavasti hyötyä silloin, kun naudat perusdieetillä kasvavat huonosti. Perusrehujen ollessa hyvälaatuisia kasvun parantumista ei yleensä tapahdu. 
SUOMEN MAATALOUSTIETEELLISEN SEURAN TIEDOTE NRO 26

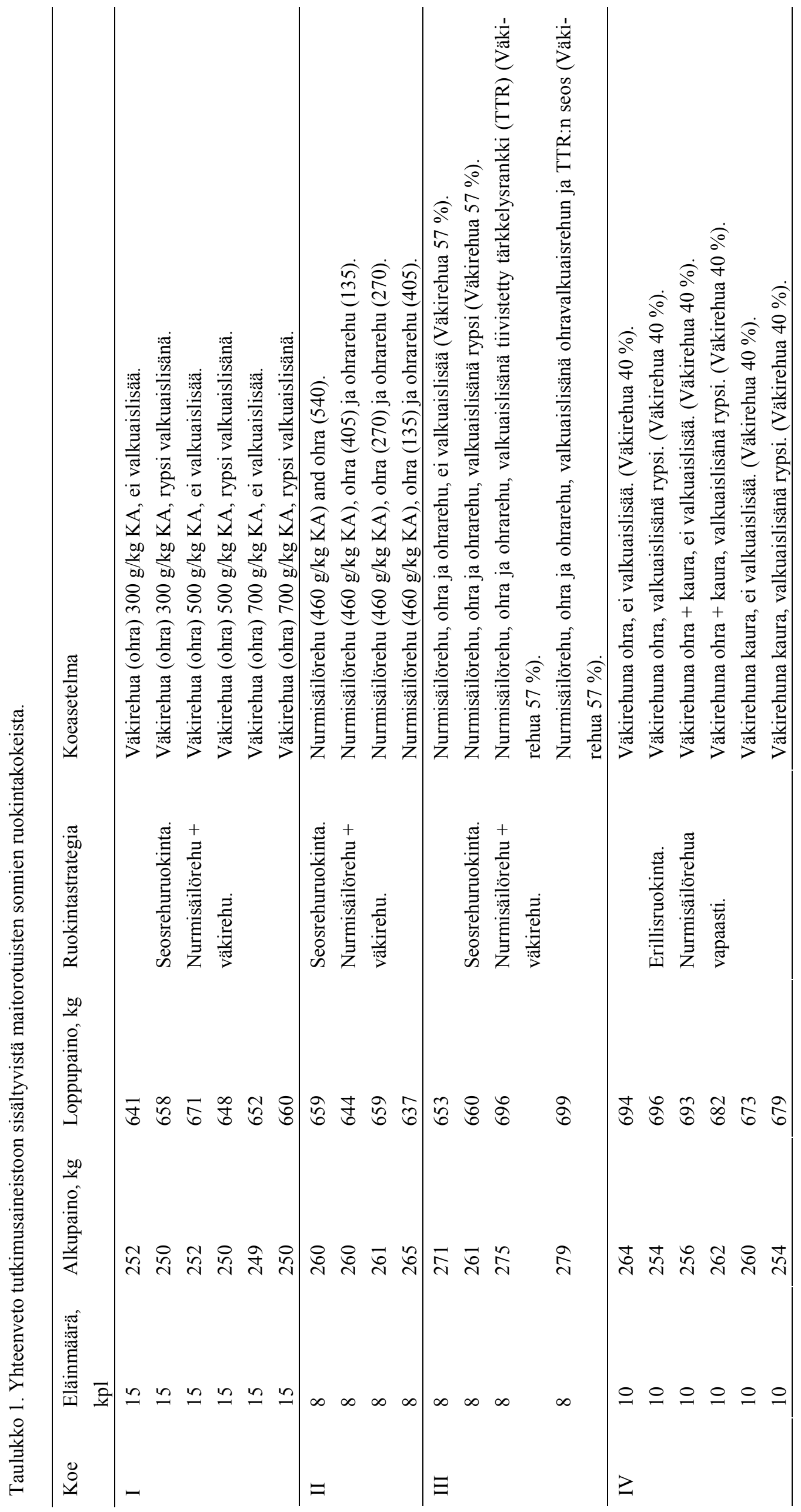




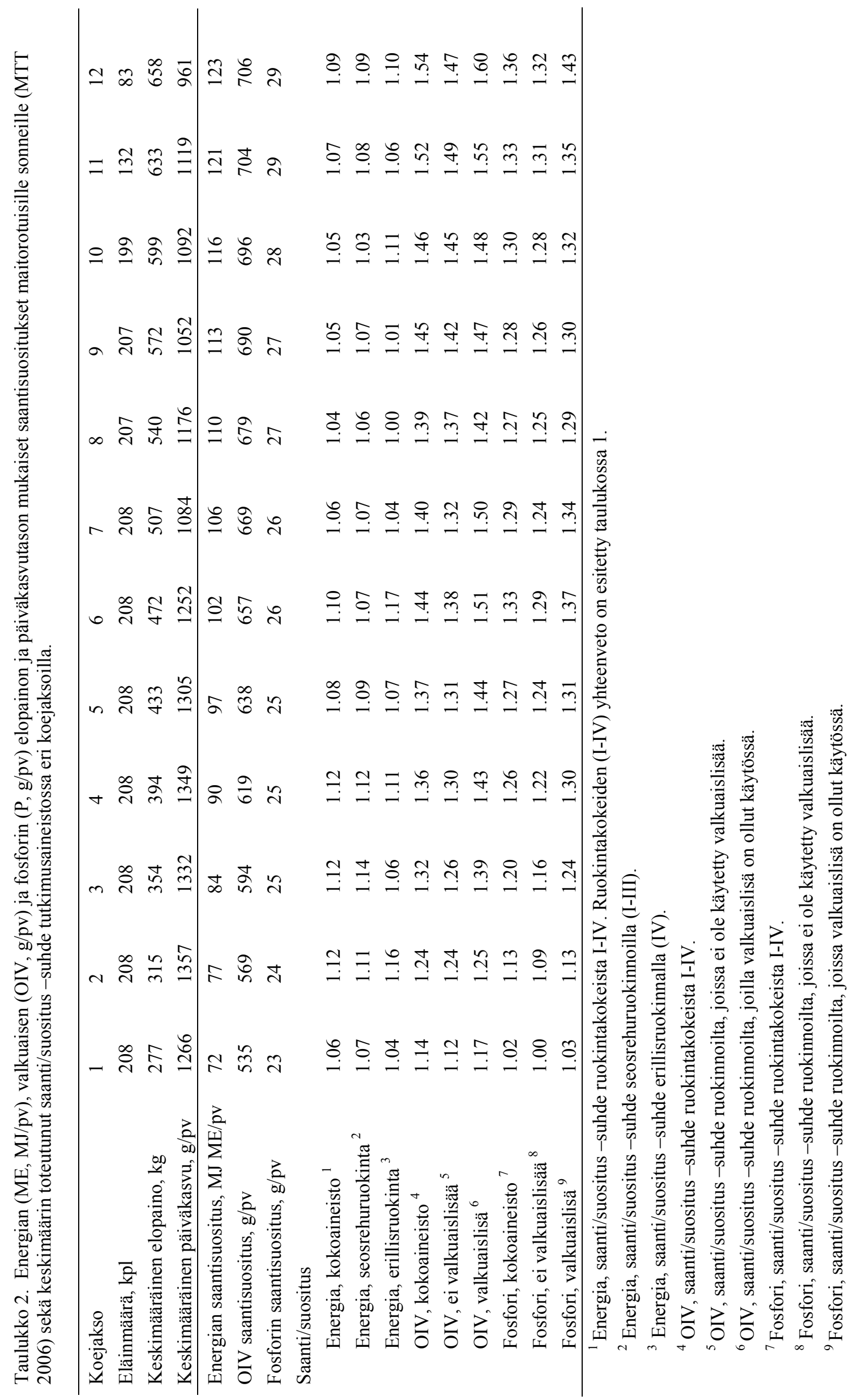




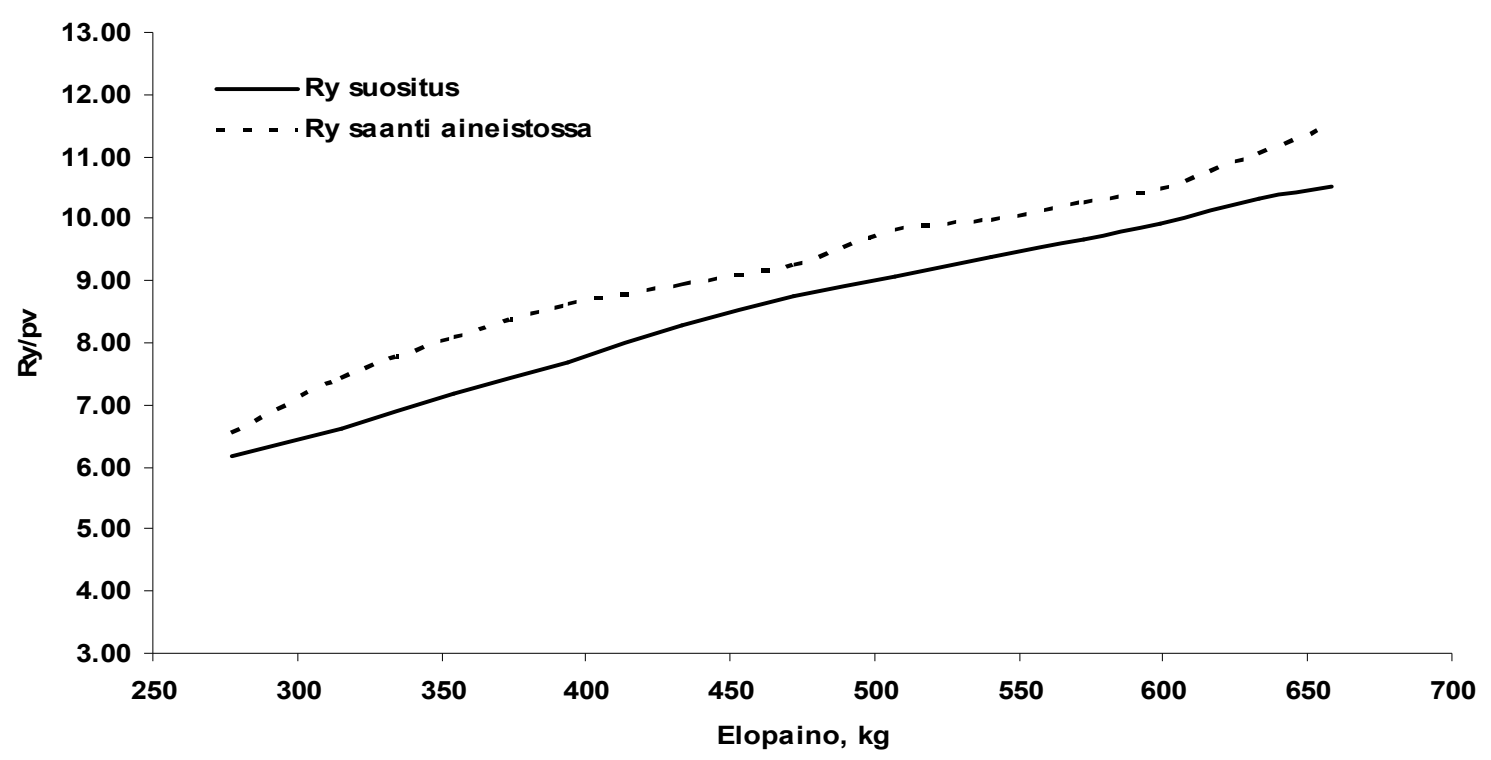

Kuva 1. Maitorotuisten sonnien Ry-saanti koeaineistossa. Katkoviiva kuvaa Ry-saantia koeaineistossa ja yhtenäinen viiva nykyistä rehutaulukoiden Ry-suositusta. Eläimet ovat olleet kokeessa puolen vuoden iästä teurastukseen (noin 17,5 kk) saakka. Keskimääräiset päiväkasvut ovat vaihdelleet koeruokinnoista riippuen välillä $1050-1300 \mathrm{~g} / \mathrm{pv}$.

Eräissä tutkimuksissa (Huhtanen ym. 1989, Aronen 1990) valkuaislisällä on ollut positiivinen vaikutus kasvuun ensimmäisillä ruokintajaksoilla (eläinten elopaino alle $300 \mathrm{~kg}$ ). Tämä selittyy sillä, että nuorella naudalla mikrobisynteesi ei yleensä riitä tyydyttämään nopean kasvun vaatimaa aminohappotarvetta. Elopainon noustessa rehun syönti kuitenkin lisääntyy ja kasvun koostumus muuttuu, jolloin mikrobisynteesin pitäisi ARC:n (1980) mukaan keskimäärin 250 elopainokilon jälkeen riittää tyydyttämään lihanaudan aminohappotarpeen. Valkuaislisä voi parantaa nautojen kasvua korkeimmissakin elopainoissa, jos perusrehut ovat huonolaatuisia ja eläinten kasvu on sen vuoksi hidasta. Tutkimuksissa valkuaislisä on parantanut lihanautojen kasvua heikosti sulavalla säilörehulla (Steen 1988) tai heinällä (Aronen 1990) ruokittaessa. Jos sonnien ruokinnassa käytetään karkearehuna nurmisäilörehun sijaan kokoviljasäilörehua, valkuaislisä yleensä parantaa jonkin verran kasvua (Joki-Tokola 2003). Sen sijaan jos peruskarkearehuna on hyvälaatuinen nurmisäilörehu, ei valkuaislisän käytölle lihanaudoilla näyttäisi olevan biologisia eikä taloudellisia perusteita (Huuskonen 2009b).

Säilörehuruokinnassa lihanautojen rehuannosta täydennetään yleensä viljalla. Viljan lisäys ruokintaan vähentää säilörehun syöntiä, mutta kokonaiskuiva-aineen syönti lisääntyy (Huuskonen 2009b). Väkirehulla saatava lisäkasvu on yleensä sitä pienempi mitä parempi kasvu saavutettaisiin pelkällä säilörehulla. Tähän vaikuttaa ensisijaisesti säilörehun sulavuus. Viljan tärkkelys hajoaa pötsissä nopeasti, jolloin se lisää mikrobien energian saantia ja siten myös ammoniakin hyväksikäyttöä mikrobisynteesiin (Thomas 1982). Hyvin matalilla väkirehutasoilla ruokittaessa ammoniakin käyttö mikrobisynteesin voi olla heikkoa, ja näissä tapauksissa valkuaisrehulisäyksellä voi olla myönteinen vaikutus lihanautojen kasvuun (Pike ym. 1988). Valkuaislisän vaikutukset ruhon koostumukseen ovat yleensä olleet hyvin vähäisiä (Huuskonen ja Lamminen 2010).

Nykyinen Suomessa käytössä oleva OIV:n saantisuositus kasvaville maitorotuisille sonneille (MTT 2006) sekä koeaineistossa toteutunut keskimääräinen OIV:n saanti on esitetty kuvassa 2 ja taulukossa 2. Koeaineistosta laskettu toteutunut OIV:n saanti oli keskimäärin 38 \% suositusta korkeampi kokeessa toteutuneilla kasvutasoilla. Suosituksen ja lasketun saannin välinen ero oli luonnollisesti suurempi ruokinnoilla, joissa valkuaislisä oli käytössä kuin ruokinnoilla ilman valkuaislisää. Nykyinen OIV-PVT -järjestelmä ei ole ilmeisesti kovinkaan hyvä valkuaisarvojärjestelmä määrittämään kasvavan naudan valkuaisen tarvetta. OIV-PVT -järjestelmässä onkin havaittu monia ongelmia (esim. Huhtanen 2005) ja järjestelmä uudistuu vuoden 2010 aikana (Huhtanen 2010). 


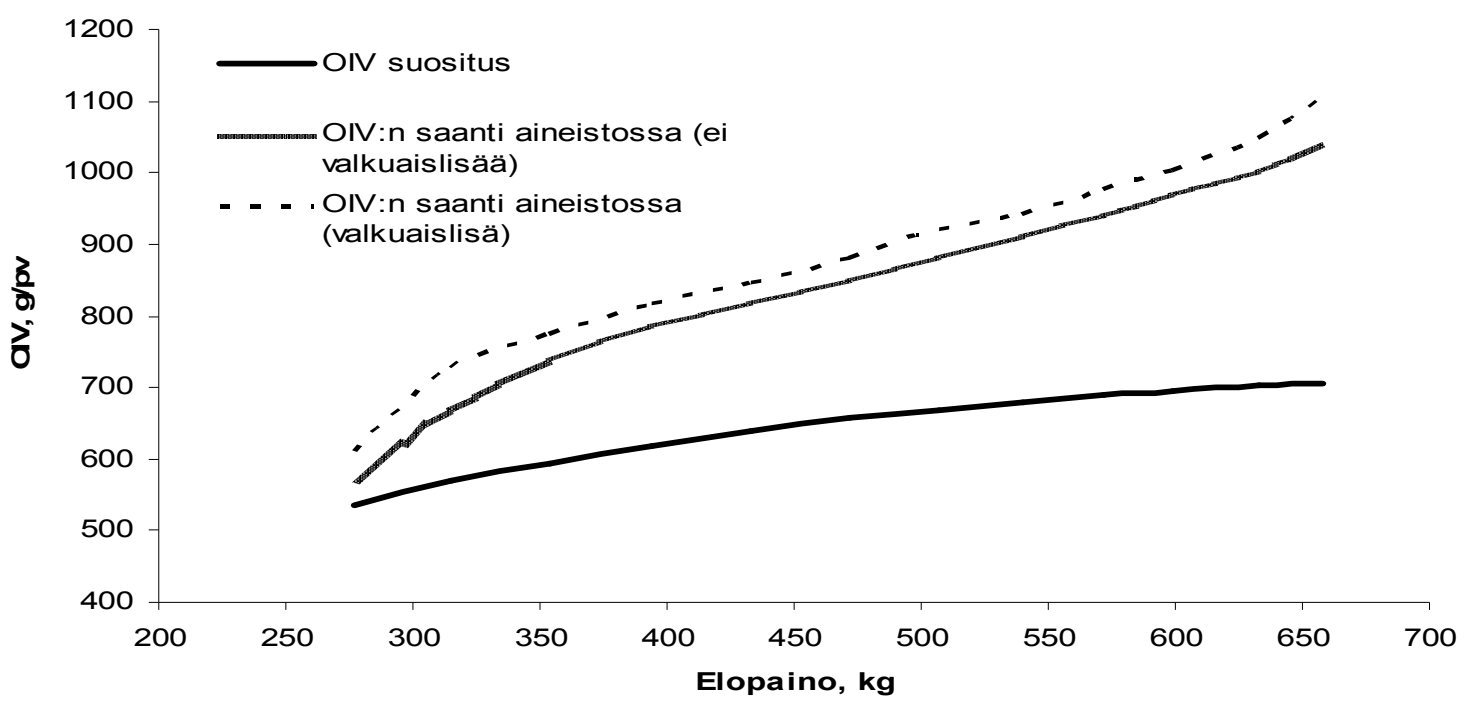

Kuva 2. Maitorotuisten sonnien OIV:n saanti koeaineistossa. Yhtenäinen viiva kuvaa nykyistä rehutaulukoiden OIV:n saantisuositusta. Keskimääräiset päiväkasvut ovat olleet koeruokinnoista riippuen 1050-1300 g/pv.

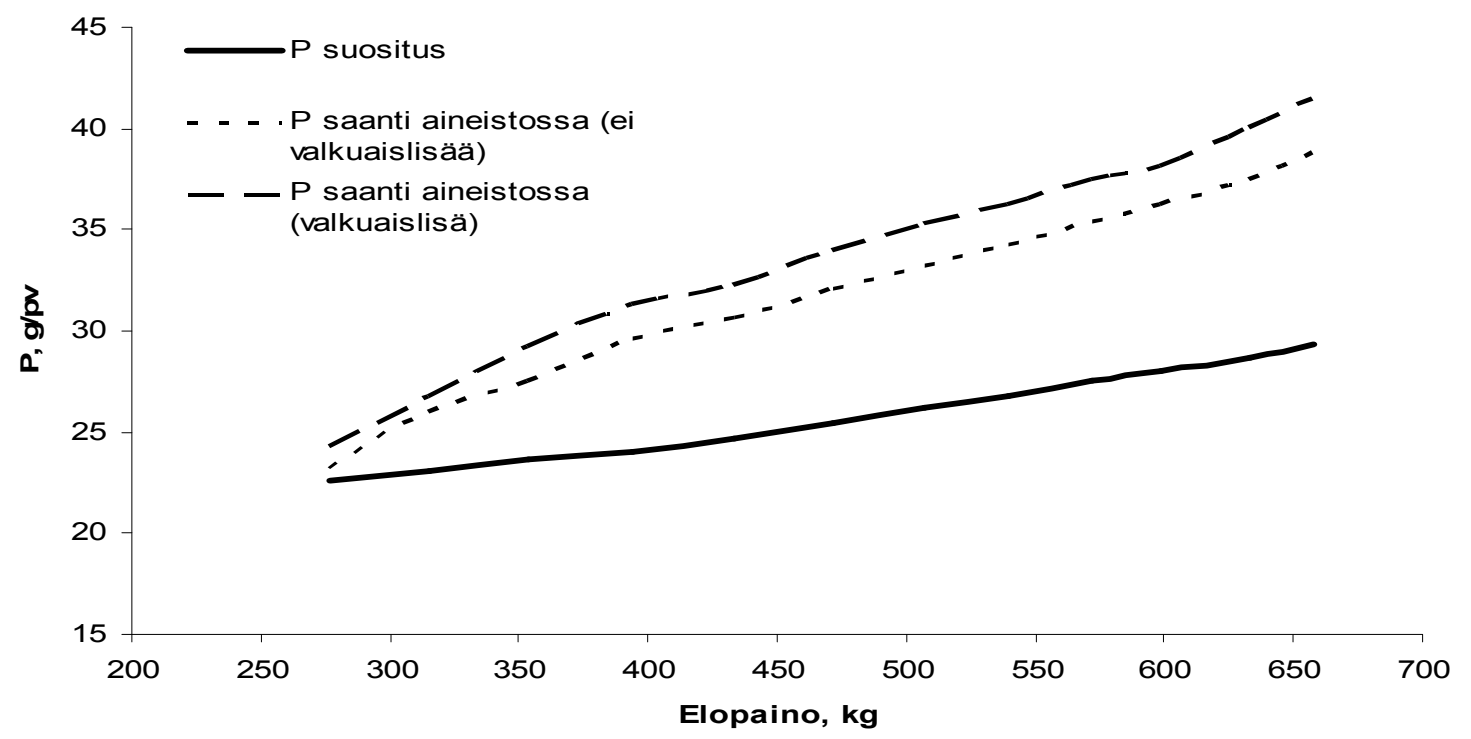

Kuva 3. Maitorotuisten sonnien fosforin saanti koeaineistossa. Yhtenäinen viiva kuvaa nykyistä rehutaulukoiden fosforin saantisuositusta. Keskimääräiset päiväkasvut ovat olleet koeruokinnoista riippuen 1050-1300 g/pv.

\section{Fosforiruokinta}

Ruokintakoeaineiston perusteella tehdyt laskelmat (Kuva 3, Taulukko 2) osoittavat, että useimmissa tapauksissa yli puolen vuoden ikäiset sonnit saavat perusrehuista (nurmisäilörehu, vilja) tarpeisiinsa nähden riittävästi fosforia. Ruokintakokeiden ajalle laskettu fosforin saanti oli keskimäärin $25 \%$ saantisuositusta korkeampi. Ensimmäisellä koejaksolla (sonnien elopaino alle $300 \mathrm{~kg}$ ) fosforin saanti oli kutakuinkin saantisuositusta vastaavalla tasolla. Saannin ja suosituksen välinen ero lisääntyi selvästi eläinten kasvaessa ollen jopa yli 30 \% viimeisten koejaksojen aikana (Taulukko 2, Kuva 3). Suosituksen ja lasketun saannin välinen ero oli suurempi ruokinnoilla, joissa valkuaislisä oli käytössä kuin ruokinnoilla ilman valkuaislisää. Tämä johtuu valkuaisrehujen suuremmasta fosforipitoisuudesta säilörehuun ja rehuviljaan verrattuna. Tulosten perusteella lisäfosforin tarjoaminen kivennäisrehujen kautta ei ole tarpeen yli puolivuotiaille sonneille. 


\section{Yhteenveto ja johtopäätökset}

Koeaineiston perusteella maitorotuinen sonni tarvitsee noin $10 \%$ nykyisiä suosituksia enemmän energiaa saavuttaakseen ruokintasuosituksissa luvatun kasvutason. Tuloksen perusteella on olemassa selkeä tarve päivittää nykyiset maitorotuisten sonnien energiaruokintasuositukset. Ruokintakoeaineiston perusteella valkuaislisän käytöllä ei saavuteta tuotosvastetta yli puolen vuoden ikäisten maitorotuisten sonnien ruokinnassa, jos karkearehuna käytetään hyvälaatuista, hyvin sulavaa nurmisäilörehua. Useimmissa tapauksissa yli puolen vuoden ikäiset sonnit saavat perusrehuista (nurmisäilörehu, vilja) tarpeisiinsa nähden riittävästi fosforia. Näin ollen lisäfosforin tarjoaminen kivennäisrehujen kautta ei ole tarpeen. Lisävalkuaisen antaminen lisää fosforin ylijäämää ruokinnassa, koska valkuaisrehujen fosforisisältö on säilörehua ja viljaa korkeampi. Ylimääräisen valkuaisen ja fosforin syöttäminen naudoille on ongelma sekä eläinten terveyden että ympäristön kannalta. Lisäksi valkuainen ja fosfori ovat suhteellisen kalliita rehukomponentteja, joten ne ovat yleensä myös turhia lisäkustannuksia.

\section{Kirjallisuus}

ARC (Agricultural Research Council) 1980. The nutrient requirements of ruminant livestock. Commonwealth Agricultural Bureaux, Farnham Royal, Surrey, UK. 351 s.

Aronen, I. 1990. Barley protein and rapeseed meal as protein supplements for growing cattle. Acta Agric. Scand. 40: 297-307.

Caplis, J., Keane, M.G., Moloney, A.P. \& O'Mara, F.B. 2005. Effects of supplementary concentrate level with grass silage, and separate or total mixed ration feeding, on performance and carcass traits of finishing steers. Ir. J. Agric. Food Res. 44: 27-43.

Huhtanen, P. 2005. Critical aspects of feed protein evaluation systems for ruminants. J. Anim. Feed Sci. 14, Suppl. 1: 145-170.

Huhtanen, P. 2010. OIV-PVT -järjestelmä uudistuu. Teoksessa: Toim. Anneli Hopponen. Maataloustieteen Päivät 2010, 12.-13.1.2010 [: esitelmät ja posterit]. 7 s. www.smts.fi

Huhtanen, P., Näsi, M. \& Khalili, H. 1989. By-products from integrated starch-ethanol production from barley in the diets of growing cattle. J. Agric. Sci. Finl. 61: 451-462.

Huuskonen, A. 2009a. The effect of cereal type (barley versus oats) and rapeseed meal supplementation on the performance of growing and finishing dairy bulls offered grass silage-based diets. Livest. Sci. 122: 53-62.

Huuskonen, A. 2009b. Concentrate feeding strategies for growing and finishing dairy bulls offered grass silagebased diets. MTT Science 1: 99 s. Väitöskirja.

Huuskonen, A., Khalili, H. \& Joki-Tokola, E. 2007a. Effects of three different concentrate proportions and rapeseed meal supplement to grass silage on animal performance of dairy-breed bulls with TMR feeding. Livest. Sci. 110: 154-165.

Huuskonen, A., Khalili, H. \& Joki-Tokola, E. 2007b. Effects of replacing different proportions of barley grain by barley fibre on performance of dairy bulls. Agric. Food Sci. 16: 232-244.

Huuskonen, A., Khalili, H. \& Joki-Tokola, E. 2008. Need for protein supplementation in the diet of growing dairy bulls fed total mixed ration based on moderate digestible grass silage and barley. Agric. Food Sci. 17: 109120.

Huuskonen, A. \& Lamminen, P. 2010. Naudan rasvoittumiseen vaikuttavat tekijät. Teoksessa: Toim. Anneli Hopponen. Maataloustieteen Päivät 2010, 12.-13.1.2010 [: esitelmät ja posterit]. 7 s. www.smts.fi

Joki-Tokola, E. 2003. Kokoviljasäilörehu ruokinnassa: lihanautojen ruokinta. Teoksessa: Kyllikki Lampinen, Taina Harmoinen, Hanne Teräväinen (toim.). Kokoviljasäilörehun tuotanto ja käyttö. MKL:n julkaisuja 993: Tieto tuottamaan 102: 38-43.

Keane, M.G., Drennan, M.J. \& Moloney, A.P. 2006. Comparison of supplementary concentrate levels with grass silage, separate or total mixed ration feeding, and duration of finishing in beef steers. Livest.Prod. Sci. 103: $169-180$.

MTT 2006. Rehutaulukot ja ruokintasuositukset. Maa- ja elintarviketalouden tutkimuskeskus, Jokioinen. Julkaistu 14.2.2006, [viitattu 6.11.2009]. Saatavissa internetistä: http://www.agronet.fi/rehutaulukot/.

Pike, I.H., Smith, G. \& Miller, E.L. 1988. An evaluation of fish meal as a protein supplement for beef cattle. Proceedings of the VIII World Conference in Animal Production. s. 427.

Steen, R.W.J. 1988. Factors affecting the utilisation of grass silage for beef production. Teoksessa: J. Frame (toim.). Efficient beef production from grass, Occasional Symposium No. 22, Br. Grassland Soc., s. 129-139.

Thomas, P.C. 1982. Utilization of conserved forages. Teoksessa: Thomson, D.J., Beever, D.E. \& Gunn, R.G. (Toim.). Forage protein in ruminant animal production. British Society of Animal Production, Occasional Publication No. 6. s. 66-76.

Tuomisto, L., Huuskonen, A., Ahola, L. \& Kauppinen, R. 2009. Different housing systems for growing dairy bulls in Northern Finland - effects on performance, behaviour and immune status. Acta Agric. Scand. Sect. A Anim. Sci. 59: 35-47. 